\title{
SEBUAH PENCARIAN, MAHASISWA AKUNTANSI YANG AKUNTANSI
}

\author{
Dian Kusumaningtyas ${ }^{1}$ \\ (Akuntansi, Fakultas Ekonomi, Universitas Nusantara PGRI Kediri) \\ diankusuma@unpkediri.ac.id \\ Erna Puspita ${ }^{2}$ \\ (Akuntansi, Fakultas Ekonomi, Universitas Nusantara PGRI Kediri) \\ ernapuspita@unpkediri.ac.id
}

\begin{abstract}
The purpose of this study was to find out how students' perceptions and understanding of accounting. And whether the aspirations of these students are in accordance with their lecture education. This research is a qualitative study in which data collection uses interview techniques. The informants interviewed $i$ were fifth semester students $(V)$ in Accounting Study Program at the University of Nusantara PGRI Kediri.

The data analysis technique uses transcendental phenomenology analysis techniques, the translation of which is Noema, Epoche (Bracketing), Noesis, Intentional Analysis and Eidetic Reduction.

The results of the study concluded that the informants chose the accounting department because they assumed that the promised employment opportunities were wide. Some informants felt that studying at an accounting study program was difficult because many counts and courses were sometimes difficult to understand. However, the informant also assumed that with accounting courses there was a lot of information about how the financial statements should be presented and how to assess the fairness of financial statements. Besides that what makes them interested is the development of accounting science that is always up to date. Some background informants chose the career they aspired to start from wanting to reduce the occurrence of corruption to be tempted by a large salary. Career planning is needed to determine the direction in accordance with the goals, the lack of understanding of accounting also influences the career aspired by the informant.
\end{abstract}

Keywords: Perception, Accounting Understanding, Career

Abstrak

Tujuan dari penelitian ini adalah untuk mengetahui bagaimana persepsi serta pemahaman mahassiwa tentang akuntansi. Dan apakah cita cita mahasiswa tersebut sesuai dengan pendidikan perkuliahannya. Penelitian inimerupakan penelitian kualitatif yang pengambilan data nya menggunakan teknik wawancara. Informan yang di wawancara i adalah mahasiswa semester lima (V) di Prodi Akuntansi Universitas Nusantara PGRI Kediri.

Teknik analisa data dengan menggunakan teknik analisis fenomenologi transcendental yang penjabarannya antara lain Noema, Epoche (Bracketing), Noesis, Intentional Analysisdan Eidetic Reduction.

Hasil penelitian meyimpulkan bahwa Informan memilih jurusan akuntansi karena beranggapan bahwa peluang kerja yang dujanjikan luas. Beberapa informan merasa bahwa kuliah di prodi akuntansi sulit karena banyak hitungan dan mata kuliah yang terkadang sulit untuk dipahami. Namun informan juga beranggapan bahwa dengan kuliah diakuntansi banyak memberikan informasi mengenai bagaimana penyajian laporan keuangan yang seharusnya serta bagaimana menilai kewajaran laporan keuangan. Selain itu yang membuat mereka tertarik adalah perkembangan ilmu akuntansi yang selalu up to date.Beberapa latar belakang informan memilih karir yang dicita-citakan dimulai dari inginnya mengurangi terjadinya korupsi hingga tergiur dengan gaji yang besar.Perencanaan karir sangat dibutuhkan untuk menentukan arah sesuai dengan yang dicita-citakan, pemahaman tentang akuntansi yang kurang juga mempengaruhi karir yang dicita-citakan oleh informan.

Kata Kunci: Persepsi, Pemahaman Akuntansi, Karir 


\section{PENDAHULUAN}

Indonesia sebagai Negara yang menghasilkan lulusan Sarjana Akuntansi terbesar di ASEAN, yaitu sebesar $45 \%$ dari seluruh lulusan mahasiswa akuntansi ASEAN yang rata-rata setiap tahunnya adalah 77.330 orang.Sumbangan sebesar $45 \%$ tersebut karena Indonesia meluluskan sekitar 35.000 mahasiswa setiap tahunnya.Informasi ini dikutip dari www.iaiglobal.or.id yang merupakan isi sambutan Prof. Mardiasmo, CA selaku Ketua Dewan Pengurus Nasional IAl.Jumlah lulusan tersebut tentu saja merupakan peluang besar bagi Indonesia untuk bisa menjadi Negara yang memiliki profesi akuntan terbesar di wilayah ASEAN.Akan tetapi, fakta menunjukkan bahwa hanya sekitar 24.000 lulusan Sarjana Akuntansi yang terdaftar sebagai Akuntan Profesional di bawah naungan Ikatan Akuntan Indonesia.

Jumlah akuntan professional tersebut masih sangat minim jika dibandingkan dengan jumlah usaha, baik skala kecil atau besar yang ada di Indonesia.Karena setiap perusahaan pasti membutuhkan setidaknya seorang akuntan untuk mendukung terciptanya pelaporan keuangan yang sesuai dengan aturan yang berlaku. Jadi sebenarnya, masih besar sekali peluang kerja yang menunggu lulusan sarjana akuntansi yang berkompeten di luar sana. Yang menjadi masalah apakah mereka siap terjun ke lapangan?Apakah kompetensi sarjana akuntansinya sudah sesuai dengan kebutuhan akuntansi di dunia kerja?Apakah mereka berkeinginan untuk menjadi seorang akuntan professional?

Merujuk pada jauhnya jumlah akuntan professional di Indonesia jika dibandingkan dengan jumlah Iulusan Sarjana Akuntansi yang dihasilkan, maka sangat perlu dikaji hal apakah yang membuat lulusan Sarjana Akuntansi tidak menentukan pilihan kariernya untuk menjadi seorang akuntan professional. Lalu, latar belakang apakah yang membuat mereka memilih kuliah pada jurusan akuntansi jika bukan untuk menjadi seorang akuntan? Tentu saja hal ini menjadi pekerjaan rumah bukan hanya bagi IAI selaku organisasi profesi yang menaungi akuntan professional, akan tetapi menjadi hal yang harus dipikirkan juga oleh dunia pendidikan khususnya bidang akuntansi.

Penelitian ini bertujuan untuk mengetahui bagaimana persepsi dan pemahaman mahasiswa tentang akuntansi dan akuntan profesional.Serta, apakah cita-cita atau pilihan karir mahasiswa tersebut sesuai dengan pendidikan yang telah ditempuh selama ini.

\section{TINJAUAN PUSTAKA}

\section{Persepsi}

Berdasarkan kamus besar bahasa Indonesia persepsi adalah tanggapan (penerimaan) langsung dari suatu yang merupakan proses seseorang untuk mengetahui hal yang dialami oleh setiap orang dalam memahami setiap informasi tentang lingkungan melalui panca indra.

Sedangkan berdasarkan Kotler dalam Aprilyan (2011) persepsi merupakan proses individu dalam memilih informasi, menafsir, mengorganisir, dan memasukkan informasi untuk menciptakan suatu gambaran yang bermakna. Menurut Wlagiro dalam Sembrirng (2009) menyatakan agar dapat membuat persepsi ada beberapa syarat yang harus terpenuhi yaitu adanya obyek yang dipersepsikan, memiliki alat indera yang 
digunakan untuk menerima stimulus dan adanya langkah perhatian yang merupakan langkah pertama dalam mengadakan persepsi.

\section{Motivasi}

Teori motivasi berkaitan erat dengan teori pengharapan (expectancy theory).Berdasarkan kamus bahasa Indonesia Motivasi berasal dari movere yang dapat diartikan sebagai dorongan atau menggerakkan.Motivasi sangatlah penting untuk dimiliki semua orang atau setiap individu karena dengan adanya motivasi mampu membuat individu menjadi giat bekerja keras dan antusas untuk mencapai hasil yang optimal.Berdasarkan Aprilyani (2011) motivasi diartikan sebagai konsep yang menguraikan tentang kekuatankekuatan individu dalam usaha mencapai sasaran.Dan juga dapat diartikan mendorong individu untuk mencapai tujuan yang diharapkan (Supardi \& Anwar, 2004).

\section{PemahamanAkuntansi}

American Accounting Association mendefinisikan akuntansi sebagai "suatu proses mengidentifikasi, mengukur dan melaporkan informasi ekonomi, untuk memungkinkan adanya penelitian dan keputusan yang jelas dan tegas bagi mereka yang menggunakan informasi tersebut" (Lutfi, 2007).

The Institute of Chartered Accountant in Australis (ICAA) dan Accounting Education Change Comission (AECC) yang dibentuk di Amerika Serikat menyatakan bahwa pendidikan akuntansi setidaknya harus dapat mempersiapkan peserta didik untuk mulai dan mengembangkan keanekaragaman karier profesional dalam bidang akuntansi. Untuk itu diperlukan tidak semata-mata pengetahuan bisnis dan akuntansi, tetapi juga penguasaan keterampilan intelektual, interpersonal dan komunikasi serta orientasi profesional (Trisniwati dan Suryaningsum 2003)

\section{PemilihanKarir}

Karir menurut Kunartinah (2003) karir mampu dilihat dari berbagai cara, antara lain : 1) Posisi yang dipegang individu dalam suatu jabatan disuatu perusahaan dalam kurun waktu tertentu; 2) Dalam kaitannya dalam mobilitas suatu organisasi; 3) Tingkat kemapanan kehidupan seseorang setelah mencapai tingkatan umur tertentu yang ditandai dengan penampilan dan gaya hidup seseorang.

Selain itu karir mampu digunakan sebagai rangkaian promosi untuk memperoleh pekerjaan yang memiliki beban dan tanggung jawab yang lebih tinggi atau penempatan karir yang lebih tinggi atau menjanjikan dalam hirarki pekerjaan seseorang sepanjang kehidupan karirnya.

Rencana karir mahasiswa yang terkadang belum nampak jelas sangat berguna dalam penyusunan program materi kuliah atau pengajaran yang akan disampaikan secara efekif kepada mahasiswa yang memerlukannya. Perencanaan karir menjadi hal yang sangat penting untuk mencapai sebuah kesuksesan (Rasmini, 2007).Sehingga mahasiswa membutuhkan stimulasi untuk mengajak mahasiswa berfikir serius tentang perencanaan karirnya sejak pada bangku kuliah sehingga diharapkan mahasiswa mampu memanfaatkan semaksimal mungkin waktu, sarana prasarana serta fasilitas kampus yang telah ada. 
Karir mahasiswa jurusan akuntansi berdasarkan Wijayanti (2001) dijelaskan bahwa faktor-faktor yang menjadi pertimbangan mahasiswa akuntansi dalam pemilihan karir sebagai akuntan publik atau non akuntan publik antara lain:

1. Penghargaan finansial

Pengahsilan atau penghargaan berupa financial diperoleh sebagai kontraprestasi dari pekerjaan yang telah dilakukan dan diyakini sebagian besar perusahaan sebagai daya tarik untuk memuaskan karyawannya. Selain itu perjhargaan financial diuji dengan tiga pertanyaan yaitu gaji awal yang tinggi, potensi kenaikan gaji dan tersedianya dana pension (Rahayu, 2003)

2. Pelatihan professional

Pelatihan professional meliputi hal yang berkaitan dengan peningkatan kompetemsi, pelatihan professional diuji dengan empat pernyataan antara lain sebelum mulai bekerja, pelatihan professional, pelatihan kerja rutin dan pengalaman kerja (Rahayu, 2003). Sedangkan wijayanti menyatakan mahasiswa akuntansi yang memilih karir menjadi akuntan public memerlukan pelatihan kerjakaeena untuk menjadi seorang akuntan public harus dapat melaksanakan pekerjaan audit dengan baik tidak cukup hanya dengan pendidikan formal dalam bangku kuliah saja namun harus ditunjang oleh pengalaman praktek dilapangan dengan jam kerja yang memadai.

3. Pengakuan professional

Pengakuan secara professional berhubungan terhadap prestasi.Berdasarkan setiyani (2005) pengakuan professional yang dipertimbangkan oleh mahasiswa yang memilih profesi akuntan publik.Hal ini menunjukkan bahwa dalam memilih profesi tidak hanya mencari penghargaan financial tetapi juga ada keinginan untuk pengakuan berprestasi dan pengembangan diri. Sedangkan menurut Rahayu (2003) pengakuan professional meliputi adanya kemungkinan bekerja dengan ahli yang lain, ada kesempatan untuk berkembang dan adanya pengakuan atas prestasi.

4. Nilai social

Nilai social menurut wijayanti menjadi salah satu factor yang menampakkan kemampuan seseorang dari sudut pandang orang lain terhadap lingkungannya.nilai social tersebuta natara lain adalah kegiatan social, kesempatan untuk berinteraksi dengan orang lain, kesempatan untuk menjalankan hobi, memperhatikan perilaku individu, malakukan pekerjaan yang lebih bergengsi dibidang karir lainnya dan dengan ahli dibidang lain.

5. Lingkungan kerja

Lingkungan kerja termasuk suasana kerja yang didalamnya terdapat sifat kerja (rutin, atraktif dan sering lembur), tingkat persaingan antar karyawan dan tekanan pekerjaan merupakan faktor dalam lingkungan kerja.Berdasarkan Felton (1994) mahasiswa tidak mempertimbangkan lingkungan kerja dalam pemilihan karirnya.

6. Pertimbangan pasar kerja 
Keamanan dalam lingkungan kerja dan mudahnya mengakses lowongan kerja menjadi salah satu factor dalam pertimbangan pasar kerja (Rahayu, 2003).Keamanan kerja merupakan factor yang mampu menyebabkan karir yang dipilih dapat bertahan dalam jangka waktu lama dan jauh dari kasus PHK.

\section{AkuntanProfesional}

Pendidikan Profesi Akuntansi (PPAk) adalah pendidikan tambahan pada pendidikan tinggi setelah program sarjana ilmu ekonomi dalam program studi akuntansi berdasarkan surat keputusan Menteri Pendidikan Nasional Republik Indonesia No. 179/U/2001 Tentang Penyelenggaraan Profesi Akuntansi (PPAk). Pendidikan Profesi Akuntansi bertujuan menghasilkan lulusan yang memiliki keahlian dibidang Akuntansi dan memberikan kompetensi keprofesiannya.

Profesi Akuntans bisa diartikan dengan mereka yang memiliki pengetahuan dan ketrampilan di bidang akuntansi melalui pendidikan formal maupun non formal. Pada umumnya profesi akuntansi memiliki beberapa spesifikasi

\section{Akuntan publik}

Akuntan publik atau auditor adalah akuntan yang bekerja dikantor akuntan publik.Jenis pekerjaan yang dilakukan seorang auditor adalah melakukan pemeriksaan laporan keuangan dan konsultasi dibidang keuangan. Jenis pekerjaan tersebut mencerminkan seorang akuntan yang bekerja dikantor akuntan publik akan selalu berhubungan dengan klien yaitu perusahan yang meminta jasa pada kantor akuntan publik (Wijayanti, 2001). Selain itu berdasarkan Jumantik (2007) menyatakan bahwa akuntan publik adalah akuntan yang bergerak dalam bidang akuntan publik yaitu menyerahkan berbagai macam jasa akuntansi untuk perusahaan perusahaan bisnis. Akuntan public merupakan profesi yang memiliki kewenangan dalam memberikan opini atas kewajaran dari laporan keuangan yang disusun manajemen (Baridwan, 1998)

\section{Akuntan perusahaan}

Auditor internal atau akuntan perusahaan adalah auditor yang bekerja dalam perusahaan (perusahaan milik pemerintah maupun perusahaan swasta) yang tugas pokoknya adalah menentukan apakah kebijakan dan prosedur yang ditetapkan oleh manajemen puncak telah dipatuhi, menentukan baik tidaknya penjagaan terhadap kekayaan suatu organisasi, menentukan efisiensi dan keefektivitas prosedur kegiatan organisasi, serta menentukan keandalan informasi yang dihasilkan oleh berbagai bagian organisasi (Trirorania, 2004).

3. Akuntan pendidik

Akuntan pendidik menurut Jumamik (2007) adalah profesi yang menghasilkan sumber daya manusia yang berkarir pada tiga bidang akuntan lainnya. Akuntan pendidik melaksanakan proses penciptaan professional bail profesi akuntan public, akuntan perusahaan dan akuntan pemerintah. Seiring dengan perekonomian yang berkembang pesat maka lapangan pekerjaan seorang akuntan juga banyak yang menginginkan.

4. Akuntan pemerintah

Akuntan pemerintah menurut Jumamik (2007) merupakan akuntan yang bekerja pada instansi pemerintah yang tugas pokoknya melakukan pemeriksaan terhadap pertanggungjawaban keuangan yang ditunjuk oleh unit-unit organisasi dalam pemerintahan. 


\section{METODE PENELITIAN}

\section{Tahapan penelitian}

Penelitian ini menggunakan beberapa tahapan antara lain

1. Indentifikasi

2. Pengambilan data

3. Tahap pengolahan data

4. Tahap analisis dan kesimpulan

\section{Lokasi Penelitian}

Lokasi penelitian ini dilaksanakan di Program Studi Akuntansi Fakultas Ekonomi Universitas Nusantara PGRI Kediri.

\section{Penentuan Informan}

Dalam menentukan informan yang akan diwawancara, peneliti menggunakan beberapa kriteria sebagai berikut:

1. Relevance

Informan yang dipilih harus sesuai dengan tujuan penelitian, yaitu mahasiswa program studi akuntansi minimal semester lima. Sehingga mereka sudah mulai memikirkan apa yang akan dikerjakan setelah lulus kuliah.

2. Rapport

Peneliti harus memiliki kedekatan dengan informan, sehingga dapat menggali informasi yang lebih mendalam.

3. Readiness

Informan harus dalam keadaan siap diwawancara, agar data yang diberikan kepada peneliti bisa relevan dan akurat.Sehingga, peneliti sangat perlu melakukan konfirmasi pada informan sebelum melakukan kegiatan wawancara.

4. Reassurance

Informan tidak mendapat paksaan dalam bentuk apapun ketika wawancara sedang berlangsung.Sehingga informasi yang disampaikan informan adalah yang sebenarnya dialami/dirasakan.

\section{Jenis dan Sumber Data}

Data yang digunakan dalam penelitian ini merupakan data primer, diperoleh melalui wawancara langsung kepada informan. Ketika melakukan wawancara, peneliti menggunakan alat bantu perekam audio ketika melakukan wawancara.

\section{Pendekatan Penelitian}


Pendekatan penelitian ini adalah kualitatif yang didasarkan pada paradigma fenomenologis.Fenomenologi merupakan pengalaman subjektif atau suatu studi tentang kesadaran dari perspektif pokok seseorang (Moleong, 2017:14). Fenomena dalam penelitian ini adalah ketimpangan jumlah akuntan professional di Indonesia jika dibandingkan dengan lulusan sarjana akuntansi.

\section{Proses Pengumpulan dan Analisis Informasi}

1. Proses pengumpulan informasi

a. Wawancara. Proses wawancara dilakukan untuk menggali informasi yang dibutuhkan peneliti, peneliti membutuhkan studi pendahuluan untuk menemukan masalah dalam penelitian yang akan diteliti secara mendalam. Peneliti memiliki keyakinan bahwa subyek penelitian mahasiswa akuntansi adalah benar dan dapat dipercaya sehingga hasilnya mampu dijadikan sebagai sumber utama dalam penulisan.

b. Dokumentasi. Dokumentasi dijadikan salah satu cara dalam pengumpulan data penelitian ini, yaitu berupa foto dan dokumen, rekaman percakapan.

2. Analisis informasi

a. Reduksi data. Reduksi data digunakan untuk menajamkan, menggolongkan, mengarahkan dan membuang yang dirasa tidak diperlukan kemudian mengkoordinasikan data sehingga tercapai kesimpulan akhir

b. Penyajian Data. Kegiatan penyusunan data yang telah diperoleh sehingga didapatkan penarikan kesimpulan yang bisa berbentuk teks naratif, matriks, grafik maupun bagan.

\section{Penafsiran dan Penarikan Kesimpulan}

Pada penarikan kesimpulan, penelitian kualitatif akan disampaikan secara naratif, yaitu merupakan penjelasan berupa kata-kata. Kesimpulan diperoleh berdasarkan data yang diperoleh dari hasil wawancara.

\section{Teknik Analisis Data}

Analisis data merupakan upaya berlanjut dan sistematis yang dilakukan saat pengumpulan data maupun setelah data terkumpul seluruhnya. Dalam penelitian ini, analisis sudah dimulai di awal, karena data yang diperoleh dalam penelitian kualitatif akan terus berkembang. Jika analisis sudah dilakukan sudah dari awal, akan mempermudah pelengkapan data jika masih ada yang kurang.

Dalam penelitian ini analisis data yang digunakan yaitu analisis fenomenologi transcendental, yang lebih berfokus pada studi kesadaran. Dalam hal ini,fenomenologi lebih menekankan pada keakuan seorang informan. Aku dalam fenomenologi merupakan pusat dari lingkungan, akhirnya mengarah pada bagaimana aku dalam tubuhku yang mengambil ruang dan tempat tertentu untuk memperoleh pengalaman. Pengalaman ini nantinya akan membentuk intuisi dari aku.

Dalam teknik analisis fenomenologi transcendental, ada beberapa hal yang harus dipahami dalam analisis data (Kamayanti, 2016) yaitu: 
1. Noema

Analisis fenomenologi selalu diawali dengan melakukan identifikasi noema yang merupakan proses analisis bagian terluar dari temuan.

2. Epoche (Bracketing)

Setelah melakukan identifikasi noema tahap selanjutnya ialah epoche yang merupakan proses pengelupasan dari yang terluar sampai dengan yang terdalam.

3. Noesis

Tahapan selanjutnya setelah epoche yaitu noesis atau pemaknaan yang lebih mendalam.Noesis merupakan kesadaran yang muncul akibat pengalaman karena dan pada waktu dan tempat tertentu.

4. Intentional Analysis

Setelah mengetahui noema dan noesis, diperlukan pemahaman lannjutan untuk mengetahui bagaimana noema bisa membentuk noesis.Pemahaman ini disebut juga intentional analysis.

5. Eidetic Reduction

Tahap terakhir yaitu menentukan hasil dari pemaknaan-pemaknaan yang telah dilakukan atau biasa disebut dengan eidetic reduction.

\section{HASIL PENELITIAN}

\section{Deskripsi Informan}

Informan dalam penelitian ini adalah mahasiswa jurusan akuntansi semester limapada Prodi Akuntansi Universitas Nusantara PGRI Kediri sebagai berikut:

1. Zulia Kartikosari.

NPM. 16.1.02.01.0030

2. Yully Nuraini

NPM. 16.1.02.01.0032

3. Bengssen Setya C

NPM. 16.1.02.01.0019

4. Tita Niya Mei Larasati NPM. 16.1.02.01.0010

5. Maria Florentina Meze

NPM. 16.1.02.01.0021

6. Nikki Ferdiana

NPM. 16.1.02.01.0005

Teknik penelitian menggunakan wawancara, informan diberikan pertanyaan sesuai dengan fokus penelitian dan jawabandari informan langsung didokumentasikan dengan menggunakan alat perekam. 


\section{Hasil Analisis Data dan Pembahasan}

Analisis hasil interview fenomenolog kepada seluruh informan dijelaskan sebagai berikut:

1. Identifikasi Noema

Tahapan identifikasi ini, peneliti menggali informasi tentang alasan informan dalammemilih jusuran akuntansi.Hasil identifikasi menunjukkan bahwa keenam informan memilih kuliah pada jurusan akuntansi karena peluang kerja bidang akuntansi yang luas.Seperti diungkapkan oleh informan Zulia yang menyatakan "...peluang kerjanya itu luas, setiap perusahaan membutuhkan staf akuntansi". Hal sama diungkapkan oleh informan Tita, yang menyatakan "prospek kerja lebih banyak dan bagus, peluang pekerjaan untuk posisi akuntan lebih banyak dibutuhkan sehingga dapat menunjang masa depan".

2. Identifikasi Epoche

Setelah identifikasi noema yang merupakan informasi terluar, selanjutnya adalah identifikasi epoche yang merupakan proses pengelupasan dari informasi terluar hingga yang paling dalam. Tahapan ini, peneliti menggali informasi tentang pemahaman informan dalam proses perkuliahan yang dijalani selam ini. Dari hasil interview diperoleh informasi bahwa informan mengalami kesulitan dalam beberapa mata kuliah, terutama mata kuliah akuntansi. Seperti yang diungkapkan oleh informan Nikki, "ada mata kuliah yang sulit dipahami", hal yang sama diungkapkan oleh informan Bengssen, "kuliah di jurusan akuntansi itu sulit".

Lebih dalam fenomenolog menggali informasi tentang pemahaman informan tentang apa itu akuntan professional, di mana sudah seharusnya seseorang yang kuliah pada jurusan akuntansi akan memilih karirnya sebagai seorang akuntan professional. Hasil yang diperoleh dari wawancara adalah,informan kurang begitu memahami tentang apa itu akuntan professional. Informan hanya tahu mengenai seorang akuntan pekerjaannya berhubungan dengan laporan keuangan perusahaan.Seperti yang disampaikan oleh informan Nikki, yangmenjelaskan bahwa "Akuntan professional adalah pihak yang independen dalammemeriksa laporan keuangan suatu entitas untuk memberikan pendapatnya.Akuntan professional adalah akuntan yang diakui oleh IAI dan memiliki register akuntan professional" dari jawaban tersebut, kalimat pertama lebih cocok untuk definisi auditor dari pada akuntan professional, sedangkan pada kalimat kedua sudah tepat.

3. Identifikasi Noesis

Selanjutnya adalah identifikasi noesis, yaitu pemaknaan yang lebih mendalam. Dijelaskan bahwa noesis adalah kesadaran yang muncul akibat suatu proses pengalaman pada suatu waktu dan tempat tertentu. Jadi pada tahapan ini, peneliti menggali terkait karir apa yang dicita-citakan setelah menyelesaikan studi S1 Akuntansi beserta alasan pemilihan karir tersebut.

Hasil interview kepada informan menunjukkan bahwa hanya satu informan atas nama Yully yang bercitacita untuk menjadi seorang akuntan professional, sampai bercita-cita memiliki Kantor Jasa Akuntan 
sendiri. Sedangkan informan lain, yaitu Nikki dan Zulia bercita-cita bekerja di bidang perpajakan, sedangkan Maria, Bengssen dan Tita bercita-cita menjadi pegawai bank. Lebih lanjut, alasan pemilihan karir tersebut dijelaskan oleh informan Yulli adalah karena ingin mengurangi tingginya korupsi di Indonesia, serta ingin menyelesaikan masalah UKM di Indonesia yang belummemahami tentang pelaporan keuangan. Sedangkan informan lain, yaitu Tita, Bengssen dan Maria menyatakan bahwa alasan pemilihan karir sebagai pegawai bank adalah gajinya yang besar. Dari jawaban tersebut, sudah sangat jelas bahwa pemahaman informan Tita, Bengssen dan Maria sangat kurang tentang akuntan professional, karena besaran gaji seorang pegawai bank akan jauh lebih kecil jika dibandingkan dengan nominal jasa akuntan yang diberikan oleh seorang akuntan professional.

4. Identifikasi Intentional Analysis

Identifikasi ini adalah pemahaman untuk mengetahui bagaimana noema dapat membentuk noesis.Sehingga pada tahapan ini fenomenolog harus menganalisis apakah alasan pemilihan jurusan kuliah informan sesuai dengan pilihan cita-cita karir yang diharapkan.Dari hasil interview kepada masingmasing informan, alasan pemilihan kuliah pada jurusan akuntansi adalah karena peluang kerja yang luas.Akan tetapi lebih banyak karir yang dipilih oleh sebagian besar informan adalah menjadi seorang pegawai bank dan pegawai koperasi.Di mana pegawai bank maupun pegawai koperasi adalah pilihan karir yang bisa juga diambil oleh lulusan bukan dari jurusan akuntansi. Pemilihan karir yang dianggap sesuai dengan jurusan akuntansi adalah yang termasuk pada akuntan profesional yang terdiri dari akuntan publik, akuntan perusahaan, akuntan pendidik, dan akuntan pemerintah.Informan Niki dan zulia yang bercita-cita ingin mendalami tentang perpajakan karena dia ingin berkarir pada bidang perpajakan. Bahkan informan zulia ingin juga menjadi seorang auditor bukan hanya staf keuangan saja. Sedangkan informan yully ingin menjadi auditor dan memiliki Kantor Jasa Akuntan sendiri. Namun secara garis besar mereka belum memiliki perencanaan karir yang terstruktur untuk mendukung tercapainya cita-cita mereka

\section{Eidetic Reduction}

Tahap terakhir yaitu menentukan hasil dari pemaknaan-pemaknaan yang telah dilakukan atau biasa disebut dengan eidetic reduction.

Dari keempat analisis di atas, maka sudah dapat kita maknai hasil penelitian ini dengan menyimpulkannya. Mahasiswa memilih jurusan akuntansi karena dianggap bahwa dengan kuliah di jurusan akuntansi mampu memperoleh karir yang bagus, meskipun berdasarkan pemahaman mereka bahwa akuntansi dirasa sulit. Salah satu anggapan tersebut disebabkan karena persepsi mereka jika akuntansi merupakan hitungan yang tugasnya menyusun laporan keuangan. Kurang pemahaman mereka akan akuntansi dan apakah itu akuntan profesional membuat beberapa dari mereka yang memiliki cita cita sebagai pegawai bank atau koperasi saja. Namun juga ada seperti informan nikki, yulli dan zulia yang menyukai perpajakan dan menginginkan memiliki kantor jasa akuntan sendiri. Perencanaan karir para informan belum terpikirkan dengan matang, bahkan ada beberapa informan yang menjelaskan bahwa 
saya kuliah dulu baru kerja. Hal ini yang dirasa kurang sesuai karena disaat kuliah akan memiliki banyak kesempatan dalam melakukan perencanaan karir sehingga cita -cita yang diharapkan tercapai.

\section{SIMPULAN DAN SARAN}

\section{Kesimpulan}

1. Informan memilih jurusan akuntansi karena beranggapan bahwa peluang kerja yang dujanjikan luas

2. Beberapa informan merasa bahwa kuliah di prodi akuntansi sulit karena banyak hitungan dan mata kuliah yang terkadang sulit untuk dipahami. Namun informan juga beranggapan bahwa dengan kuliah diakuntansi banyak memberikan informasi mengenai bagaimana penyajian laporan keuangan yang seharusnya serta bagaimana menilai kewajaran laporan keuangan. Selain itu yang membuat mereka tertarik adalah perkembangan ilmu akuntansi yang selalu up to date.

3. Beberapa latar belakang informan memilih karir yang dicita-citakan dimulai dari inginnya mengurangi terjadinya korupsi hingga tergiur dengan gaji yang besar.

4. Perencanaan karir sangat dibutuhkan untuk menentukan arah sesuai dengan yang dicita-citakan, pemahaman tentang akuntansi yang kurang juga mempengaruhi karir yang dicita-citakan oleh informan.

\section{Saran}

Beberapa saran yang dapat peneliti sampaikan berdasarkan hasil penelitian adalah seharusnya program studi bisa memberikan sarana atau wadah diskusi bagi mahasiswanya dalam hal pemilihan karier yang tepat setelah lulus kuliah. Selain penting bagi masa depan mahasiswa setelah lulus, hal tersebut juga penting bagi mahasiswa, karena ketika lulusan bekerja sesuai dengan bidang pendidikan juga akan memberikan nilai tambah bagi program studi yang bersangkutan.

\section{DAFTAR PUSTAKA}

Aprylian, L.A. 2011. " Faktor-Faktor Yang Mempengaruhi Mahasiswa Akuntansi Dalam Pemilihan Karir Menjadi Akuntan Publik", Skripsi, Semarang: Program Sarjana Fakultas Ekonomi Universitas Diponegoro

Baridwan, Zaki. 1998. Intermediate Accounting. BPFE. Yogyakarta

Felton, Sandra, Nola, Buhr, Margot N. 1994. Factor influencing the bussiness students choice of a career in chartered Accounting. Issues in Accounting Education. HIm 131-141

Jumamik. 2007. " Persepsi Mahasiswa Akuntansi Mengenai Faktor-Faktor Yang Mempengaruhi Pemilihan Karir Akuntan.". Skripsi. USM. Semarang

Kamayanti, A. 2016. Metodologi Penelitian Kualitatif Akuntansi. (A. D. Mulawarman, Ed.). Jakarta: Ngapurancang.

Kunartinah. 2003. "Perilaku Mahasiswa Akuntansi Di STIE Stikubank Semarang Dan Faktor-Faktor Yang Mempengaruhi Pemilihan Karir Sebagai Akuntan Publik". Jurnal Bisnis dan Ekonomi. Vol.10

Moleong, L. J. 2017. Metode Penelitian Kualitatif (36th ed.). Bandung: PT Remaja Rosdakarya.

Rahayu, Sri. Eko Arief Sudaryono, Doddy Setiawan. 2003. "Persepsi Mahasiswa Akuntansi Mengenai FaktorFaktor Yang Mempengaruhi Pemilihan Karir". Simposium Nasional Akuntansi VI. Surabaya

Rasmini, N.K. 2007. "Faktor-Faktor Yang Berpengaruh Pada Keputusan Pemilihan Profesi Akuntan Publik Dan Non Akuntan Publik Pada Mahasiswa", Buletin Studi Ekonomi. Vol.12 No.3 Hal 351-363 
Sembiring, M.S. 2-9. "Faktor-Faktor Yang Mempengaruhi Pemilihan Karir Menjadi Akuntan Publik Oleh Mahasiswa Departemen Akuntansi Fakultas Ekonomi USU Medan". Skripsi. Medan: Universitas Sumatera Utara

Setyani, R. 2006. "Pengaruh Indeks Prestasi Kumulatif Dan Persepsi Mahasiswa Akuntansi Dalam Memilih Profesi Sebagai Akuntan Publik Dan Non Akuntan Publik. Skripsi . Semarang : Program Pascasarjana Universitas Diponegoro.

Supardi dan Anwar. 2004, Motivasi Kerja. Yogyakarta : Puri Arsita Anam

Surat Keputusan Menteri Pendidikan Nasional Republik Indonesia No. 179/U/2001 Tentang Penyelenggaraan Profesi Akuntansi (PPAk) mahasiswa akuntansi". KOMPAK, No.3. Halaman 359-383

Trisnawati, Eka Indah dan Suryaningrum, Sri. 2003. "Pengaruh Kecerdasan Emosional Terhadap Tingkat Pemahaman Akuntansi". Skripsi

Trirorania, Y. 2004. "Faktor-Faktor Yang Mempengaruhi Pemilihan Profesi Akuntan Oleh Mahasiswa Akuntansi". Skripsi. Program Sarjana. Yogyakarta: Universitas Pembangunan Nasional.

Wijayanti, Lilies Endang. 2001. "Faktor-Faktor Yang Mempengaruhi Pilihan Karir Mahasiswa Akuntansi". Kompak.3. HIm 359-383

www.iaiglobal.or.id 